\title{
SABERES DA AÇÃO PEDAGÓGICA DE PROFESSORES FORMADORES DA ÁREA DE ENSINO DE HISTÓRIA
}

\author{
Augusto Ridson de Araújo Miranda \\ Professor da rede estadual pública de ensino e da Universidade das Américas. Mestre em Educação \\ pela Universidade Estadual do Ceará. E-mail: ridsonufchistoria@ yahoo.com.br \\ Antonio Germano Magalhães Junior \\ Professor do Departamento de História e do Programa de Pós-Graduação em Educação da \\ Universidade Estadual do Ceará. Pós-doutor em Educação pela Universidade Federal do Rio Grande \\ do Norte. E-mail: germano.junior@uece.br \\ Pesquisa financiada com apoio do Conselho Nacional de Desenvolvimento Científico e \\ Tecnológico (CNPq), via Edital Universal 2014.
}

\section{RESUMO}

O presente artigo objetiva apresentar uma pesquisa realizada com professores do curso de licenciatura em História da Universidade Estadual do Ceará, localizada no campus de Fortaleza, e o repertório de conhecimentos e referenciais para a prática docente em Ensino de História por estes mencionados e/ou mobilizados nas entrevistas cedidas e aulas observadas na realização desta pesquisa, isto é, os saberes da ação pedagógica, nos dizeres de Gauthier et al (1998). Tomamos como metodologia de pesquisa o estudo de caso único (STAKE, 2007), do tipo descritivo-explanatório (YIN, 2005), no paradigma interpretativista. Realizamos entrevistas semiestruturadas e observação de aulas de duas professoras do caso analisado. $\mathrm{O}$ recorte temporal norteador do estudo foi o semestre de 2015.1. Como fundamentação teóricometodológica, foram considerados os estudos de Almeida (2012), Fonseca (2009), Gauthier et al (1998), Monteiro (2007), Rüsen (2011), Tardif (2008), Tardif; Lessard (2011), Zamboni; Fonseca (2008), dentre outros. A pesquisa apontou para um variado repertório de percursos formativos e saberes mobilizados nas práticas docentes dos sujeitos de pesquisa, do qual se valeram para se legitimarem como os professores mais capacitados para exercer a docência na área de História e Ensino. Concluímos que, embora haja uma diversidade de referenciais remetidos e/ou mobilizados, com destaque para a perspectiva do Ensino de História mediado por fontes, ainda se observa a força dos saberes históricos de referência se sobrepujando aos saberes próprios do Ensino de História.

Palavras-chave: Ensino de História. Professores Formadores. Saberes da ação pedagógica.

\section{KNOWLEDGE OF HISTORY PROFESSORS' PEDAGOGICAL ACTIONS}

\begin{abstract}
This article presents a research whose protagonists are the History professors of the State University of Ceará, Fortaleza campus, and the repertoire of knowledge and references for History teaching practice mentioned by them in the interview and/or mobilized by them in the observed classes, known as the knowledge of teaching actions (GAUTHIER et al., 1998). The single case study (STAKE, 2007), with descriptive-explanatory (YIN, 2005) in the interpretative paradigm, was the research methodology. To produce the data, two professors were interviewed and their classes were observed in 2015.1. The theoretical-methodological basis lies on Almeida (2012), Fonseca (2009), Gauthier et al. (1998), Monteiro (2007), Rüsen
\end{abstract}


Linguagens, Educação e Sociedade, Teresina, Ano 23, n. 40, set./dez. 2018.

Revista do Programa de Pós- Graduação em Educação da UFPI| ISSN 2526-8449 (Eletrônico) 1518-0743 (Impresso)

https://doi.org/10.26694/les.v1i40.7753

(2011), Tardif (2008), Tardif; Lessard (2009), Zamboni; Fonseca (2008), among others. The research pointed out a varied repertoire of educative paths and mobilized knowledge in the professors' teaching practices, which is their reference to legitimate themselves as better trained History professors. The research concludes that, although there is a diversity of mentioned and/or mobilized references, highlighting the perspective of History Teaching mediated by sources, the strength of historical knowledge of reference, surpassing the specific knowledge of History Teaching was still observed

Keywords: History. State University of Ceará. Knowledge of pedagogical action

\section{SABERES DE LA ACCIÓN PEDAGÓGICA DE PROFESORES FORMADORES DEL ÁREA DE ENSEÑANZA DE HISTORIA}

\section{RESUMEN}

El presente artículo tiene como objetivo presentar una investigación realizada con profesores del curso de licenciatura en Historia de la Universidad Estatal de Ceará, ubicada en el campus de Fortaleza, y el repertorio de conocimientos y referenciales para la práctica docente en Enseñanza de Historia por estos mencionados y / o movilizados en las entrevistas y em las clases observadas en la realización de esta investigación, es decir, los saberes de la acción pedagógica, en los términos de Gauthier et al (1998). Tomamos como metodología de investigación el estudio de caso único (STAKE, 2007) y descriptivo-explicativo (YIN, 2005), en el paradigma interpretativista. Se realizaron entrevistas semiestructuradas y observación de clases de dos profesoras del caso analizado. El recorte temporal orientador del estudio fue el semestre de 2015.1. Como base teórico-metodológica, fueron considerados los estudios de Almeida (2012), Fonseca (2009), Gauthier et al (1998), Monteiro (2007), Rüsen (2011), Tardif (2008), Tardif; Lessard (2011), Zamboni; Fonseca (2008), entre otros. La investigación apuntó a un variado repertorio de itinerarios formativos y saberes movilizados en las prácticas docentes de los sujetos de investigación, del cual se valieron para legitimarse como los profesores más capacitados para ejercer la docencia en el área de Historia y Enseñanza. Concluimos que, aunque hay una diversidad de referenciales remitidos y / o movilizados, con destaque para la perspectiva de la Enseñanza de Historia mediada por fuentes, todavía se observa la fuerza de los saberes históricos de referencia sobrepasandose a los saberes propios de la Enseñanza de Historia.

Palabras clave: Enseñanza de Historia. Profesores Formadores. Saberes de la acción pedagógica

\section{Introdução}

O presente artigo visa discorrer parte dos resultados de investigação acerca dos professores de uma das áreas do curso de licenciatura em História da Universidade Estadual do Ceará (UECE) em Fortaleza, a área de História e Ensino, investigada durante o ano de 2015. Com efeito, iremos problematizar acerca do repertório de conhecimentos e referenciais 
Linguagens, Educação e Sociedade, Teresina, Ano 23, n. 40, set./dez. 2018.

Revista do Programa de Pós- Graduação em Educação da UFPI| ISSN 2526-8449 (Eletrônico) 1518-0743 (Impresso)

https://doi.org/10.26694/les.v1i40.7753

para a prática docente em Ensino de História mencionados e/ou mobilizados pelos professores universitários nas entrevistas cedidas para a pesquisa e aulas observadas na realização desta pesquisa (durante o semestre letivo de 2015.1), isto é, os saberes da ação pedagógica, nos dizeres de Gauthier et al (1998).

O método de pesquisa empregado se deu na perspectiva de um estudo de caso do tipo único (STAKE, 2007), que é a área de História e Ensino do curso de História da UECE em Fortaleza; de tipo descritivo-explanatório (YIN, 2005), isto é, voltado para a compreensão minuciosa do caso; e partindo do paradigma interpretativista, cujo objetivo é o de compreender a realidade partindo da lógica interna de seus sujeitos envolvidos.

Tal investigação contribuiu para a realização de uma pesquisa de maior espectro denominada "Cartografia das relações de saber/poder dos professores das licenciaturas", financiada pelo Conselho Nacional de Desenvolvimento Científico e Tecnológico (CNPq) via Edital Universal 2014 deste Conselho, e que visa investigar as trajetórias formativas, os saberes e as práticas docentes dos professores das licenciaturas da UECE, universidade pública de referência regional em Formação de Professores; a pesquisa está igualmente vinculada ao Programa de Pós-Graduação em Educação, cuja ênfase em Formação de Professores o torna referência nacional nesta área de investigação. Partindo desta pesquisa maior, tomamos como categoria central de problematização dos dados da investigação para este artigo os saberes da ação pedagógica, que articulam as categorias formação docente, saberes docentes e práticas docentes, o que possibilitará melhor compreensão do objeto estudado, uma vez que os saberes da ação pedagógica são os saberes articuladores das experiências adquiridas em vários momentos e modalidades da formação docente com a experiência prática cotidiana, mobilizando conhecimentos específicos da matéria ensinada.

$\mathrm{O}$ artigo está dividido em 5 tópicos, fora a Introdução: o primeiro visa problematizar a indissociabilidade entre as categorias formação docente, saberes docentes e práticas docentes, visando compreender onde e quando são formados os saberes docentes ao longo de um percurso formativo de um professor (considerando as vivências da prática docente também como momentos formativos); o segundo visa evidenciar os saberes da ação pedagógica entre os demais saberes docentes, focalizando em 5 tendências, compiladas por nós, de saberes da ação pedagógica acerca do Ensino de História que vêm formando e orientando a prática de professores de História; o terceiro problematiza a coleta de dados acerca dos saberes da ação pedagógica de professores e justifica a escolha, para este artigo, 
Linguagens, Educação e Sociedade, Teresina, Ano 23, n. 40, set./dez. 2018.

Revista do Programa de Pós- Graduação em Educação da UFPI| ISSN 2526-8449 (Eletrônico) 1518-0743 (Impresso)

https://doi.org/10.26694/les.v1i40.7753

por 2 dos 6 sujeitos de pesquisa, por terem sido os em maior evidência em nossa investigação; o quarto apresenta a análise, tanto das narrativas das histórias de formação docente, como das aulas observadas das 2 professoras escolhidas para este artigo; no quinto, as Considerações Finais, problematizamos os dados da análise anterior contextualizando com o todo do caso pesquisado, constatando uma variedade de saberes docentes mobilizados, incluindo perspectivas atuais dos saberes da ação pedagógica, ainda que haja relativo domínio dos saberes históricos aos saberes pedagógicos nas práticas de formação dos professores de História, o que nos leva a propor mudanças nas diretrizes acerca das formações dos professores no Brasil, bem como dos critérios de seleção/concurso de professores formadores no cenário nacional.

\section{Entre o percurso formativo, os múltiplos saberes e as práticas docentes: os saberes da ação pedagógica}

Os docentes, segundo Tardif; Lessard (2011), praticam um ofício feito de múltiplos saberes constituídos ao longo de um processo formativo triplamente dimensional: depende do tempo, dos locais de atuação, da significação do aprendizado e da interpretação intersubjetiva destes com as realidades educacionais. Isto quer dizer que os docentes formam e são formados para adquirir e ensinar saberes: entre estes processos, complementares e dinâmicos, se encontram as práticas docentes, o que nos leva a advogar em torno de uma indissociabilidade entre as categorias formação docente, saberes docentes e práticas docentes, sobretudo as práticas de ensino.

Para que tal indissociabilidade ocorra, é necessário, segundo Tardif (2008), um autoconhecimento advindo da reflexividade (saber) dos professores de quando e como foram formados, e porque praticam o que sabem/dizem saber; tal autorreflexividade aproxima tal debate dos estudos da Epistemologia da Prática Docente, como argumenta Pimenta (2010), pois existe uma lógica própria das práticas docentes, a partir de seus locais de atuação, de seus saberes e de sua formação, que dá à docência uma profissionalidade singular; também aproxima-se das relações de saber-poder argumentadas por Foucault (2007), como defende Monteiro (2007), uma vez que tanto o saber dá especificidade e poder a quem sabe, como os locais de produção e circulação de saber qualificam o poder do saber e de quem sabe.

$\mathrm{O}$ ato de tomar o percurso formativo, nos dizeres de Monteiro (2007), como eixo condutor das categorias, partiu de nosso entendimento de que os saberes são adquiridos ao 
longo de um tempo e espaço, ao longo de vivências específicas de cada sujeito (em que as práticas docentes fazem parte dessas vivências), tracejadas nas várias tramas históricas de cada $\mathrm{um}^{1}$, o que nos levou a investigar quando e como nossos sujeitos de pesquisa adquiriram saberes para ensinar no curso de História da UECE em Fortaleza. Entretanto, compreendemos que existem saberes específicos para ensinar História, adquiridos ao longo de formações específicas, como a Inicial (universitária, a partir da Didática específica na disciplina ensinada), a Continuada (nos espaços formais pós-graduados, como Especializações, cursos de aperfeiçoamento, Mestrados, Doutorados etc.) e a Contínua (nos espaços e momentos nãoformais, como minicursos, experiências profissionais, leituras, e demais experiências humanas); e acrescentamos, a partir de Tardif (2008), que estes saberes específicos são formados a partir da escolarização, com referenciais de práticas docentes (no geral e, com efeito, em História) advindos dos professores que tiveram contato. Estes múltiplos referenciais se somam aos demais saberes mobilizados na ação pedagógica, e são ressignificados nas tramas de cada história de vida de cada professor, construindo um novo arcabouço mobilizado via prática docente. Esta constatação é fundamental para compreendermos a profunda interconexão entre saberes e formação nas falas dos sujeitos de pesquisa que apresentaremos ao longo do texto, sobretudo no quarto tópico.

\section{Os saberes da ação pedagógica como saberes em destaque dos professores de História}

Os saberes docentes podem ser, didaticamente, agrupados em quatro grandes grupos, segundo Gauthier et al (1998) e Tardif (2008): saberes pedagógicos (estes subdivididos em saberes curriculares, da tradição pedagógica e das ciências da educação); saberes experienciais; saberes específicos disciplinares; e saberes da ação pedagógica, que congregam os demais saberes na construção de um saber original e interdisciplinar. Partimos dos estudos de Gauthier et al (1998) para argumentar que são os saberes da ação pedagógica os saberes que conferem profissionalidade específica aos docentes, pois por mobilizarem todos os saberes em um só, acabam por pensar a gestão dos conteúdos e da sala de aula como um só, criando condições particulares a um docente.

\footnotetext{
${ }^{1}$ Compreendemos o conceito de trama a partir de Veyne (2008), autor que discute que as tramas históricas dos sujeitos são produto das interações intersubjetivas de si com outras tramas, em que o historiador narre parte das possibilidades de trama histórica criadas nestas interações. Tal forma de investigação nos aproxima da metodologia de História Oral de vida; embora não a tenhamos realizado de forma efetiva, não negamos sua influência na execução das entrevistas e no tratamento de dados.
} 
Linguagens, Educação e Sociedade, Teresina, Ano 23, n. 40, set./dez. 2018.

Revista do Programa de Pós- Graduação em Educação da UFPI| ISSN 2526-8449 (Eletrônico) 1518-0743 (Impresso)

https://doi.org/10.26694/les.v1i40.7753

Como partimos da escolha para os sujeitos de pesquisa os docentes em História formadores de outros docentes em História, que ensinam disciplinas específicas para o Ensino de História, os saberes da ação pedagógica se convertem em critérios qualitativos de investigação dos saberes docentes no caso analisado, uma vez que, em teoria, estes docentes essencialmente ensinam conteúdos formativos dos saberes da ação pedagógica na Formação Inicial. Se faz, portanto, necessário melhor conceituar o que são saberes da ação pedagógica e quais seriam as possibilidades destes na historicidade do Ensino de História.

Com efeito, saberes da ação pedagógica são saberes para o "ensino de", oriundos da prática docente por excelência, que nascidos ou não interdisciplinarmente, articulam saberes pedagógicos, experienciais e disciplinares ao serem mobilizados para ensinar, gerando assim saberes específicos para o ensino de determinada disciplina ou temática. Partem de três princípios geradores para que possam ser efetivamente considerados como tal, como argumentam Gauthier et al (1998). Segundo estes autores, o primeiro princípio é que os saberes da ação pedagógica só se tornam como tal no momento em que as práticas de ensino passam a ser repertório formativo de outros professores e realizadas (replicadas) em outros espaços pedagógicos quando tornadas públicas em pesquisas reflexivas (SCHÖN, 1992) ou em observações na sala de aula de práticas de ensino: isto significa que os saberes da ação pedagógica precisam ser publicizados. O segundo é relacionado ao primeiro e igualmente relevante: a publicidade desses saberes os torna poderosos instrumentos de constituição de profissionalidade da docência, gerando um repertório de conhecimentos exclusivo de um grupo docente: o saber da ação pedagógica é um saber de expertise de determinado grupo docente. O terceiro é que, ao articularem saberes de distintas epistemologias, os saberes da ação pedagógica realizam uma tripla transformação epistemológica, ressignificando os saberes pedagógicos e os saberes específicos da disciplina ensinada, e criam um campo didático específico (a exemplo da História, da Didática da História), possibilitando inclusive produzir reflexões acerca das particularidades da aprendizagem e do ensino de uma ciência.

Compilamos, por meio de um levantamento bibliográfico, 5 tendências de práticas docentes em História convertidas em saberes formativos e reproduzidos no Brasil; contudo, considerando os três princípios supracitados como norteadores, podemos classificar apenas 2 dessas tendências como efetivamente saberes da ação pedagógica. A primeira tendência, embasada nas Escolas Metódicas alemã, com Leopold Von Ranke (1795-1886), e francesa, com Charles-Victor Langlois (1863-1929) e Charles Seignobos (1854-1942), de História 
Política, foi amplamente difundida ao longo do século XIX e dominou, segundo Bittencourt (2009), até meados do século XX, nas permanências de práticas docentes nos cotidianos das salas de aula. Bittencourt (2009, p.79), aponta que:

Historiadores do Instituto Histórico e Geográfico do Brasil (IHGB) haviam fornecido, no decorrer do século XIX, as bases de uma história nacional dividida em períodos definidos pela ação política: a descoberta do Brasil - o nascimento da nação que era notadamente branca, européia e cristã foi constituído no período da colonização; a Independência e o estado monárquico, que possibilitaram a integridade territorial e o surgimento de uma 'grande nação'. A História do Brasil dos programas curriculares e dos livros didáticos possuía o mesmo arcabouço, mas, na prática escolar, paradoxalmente, foi um conteúdo complementar na configuração de uma identidade nacional. A história da 'genealogia da nação' baseava-se na inserção do Brasil no mundo europeu, e era este mundo a matriz ou o berço da Nação.

Pelos motivos supracitados, Bittencourt (2009) o chama de "currículo humanístico". Interessa aqui sobretudo seu aspecto procedimental: a crença no rigor aos documentos escritos gerou uma prática historiográfica reprodutivista e também um ensino reprodutivo; oriundos do ensino jesuítico, trabalharam em favor de uma crença na exposição oral e na aprendizagem por repetição. Bittencourt (2009, pp. 84-86) indica que hábitos de “aquisição de conhecimentos", calcados nos métodos mnemônicos (que, por sua vez, assentados na tradição antigo-medieval de associação entre História e Memória), na cronologia linear, nos "quadros sinóticos" (associação entre imagens, textos e fatos) e inseridos nos manuais didáticos advindos do Colégio Pedro II, deram a tônica dessa tendência, misturados a uma crença em um amálgama entre a História Humana e a "História Sagrada".

Dessa forma, essa primeira tendência não se configura como saber da ação pedagógica (embora influencie profundamente como tradição cultural escolar) porque não atende a nenhum dos fatores supracitados como necessários e justificativos: não há processo de reflexão científica, e sim de repetição; contribuiu para uma desprofissionalização dos professores de História (não requisitava formação específica em História para ensinar); e se caracterizava mais por sobreposição de conhecimentos históricos produzidos - parcamente atrelados até à ciência histórica do século XIX, que tinha prática historiográfica similar - até o momento na prática de ensino. Pelo abordado por Barca (2001) e Magalhães (2003), essa prática de ensino reinou na Europa até, no mínimo, os anos 1960, motivo pelo qual muitos estudantes, nos ensinos secundários europeus nessa década (cujas matérias eram eletivas pelos estudantes nesse período escolar), não optavam pela disciplina História. 
Linguagens, Educação e Sociedade, Teresina, Ano 23, n. 40, set./dez. 2018.

Revista do Programa de Pós- Graduação em Educação da UFPI| ISSN 2526-8449 (Eletrônico) 1518-0743 (Impresso)

https://doi.org/10.26694/les.v1i40.7753

A segunda tendência (dominante do final do século XIX até os anos 1960) vem romper com os enfoques para o Ensino de História da primeira tendência, embora metodologicamente não incorporasse as substanciais mudanças epistemológicas da História a esta contemporâneas: o historicismo, o materialismo histórico-dialético e a "revolução epistemológica" da École D'Annales - que, conforme Burke (1997), ampliou o espectro de fontes e de objetos de pesquisa. Seu enfoque é o cientificismo da historiografia do século XIX, segundo Bittencourt (2009), e é praticado porque no mundo ocidental, o currículo humanístico (a primeira tendência) foi duramente criticado pelos grupos defensores da modernização técnico-urbana advinda do capitalismo industrial e financeiro, pois este não atendia à preparação para o trabalho técnicoindustrial. A ênfase nas Ciências da Natureza induziu a um pragmatismo no ensino das ciências humanas, reforçando o caráter iluminista, cronológico e de crença no evolucionismo progressista da tendência anterior, mas afastando-a do ensino religioso. No Brasil, dos anos 1930 aos anos 1960, governos progressistas, como os de Vargas e das demais tendências nacional-desenvolvimentistas, reforçando a crença em um ensino de orientação patriótica e ordeira, investiram no misto de práticas entre a primeira e a segunda tendência, com ênfase nas datas comemorativas para reforçar idealismos de integração nacional. Uma vez que a gestão dos conteúdos e da sala de aula não rompem com a primeira tendência, também não podemos considerar essa tendência como saber da ação pedagógica.

A terceira tendência surge decorrente das duas primeiras, sobretudo como crítica quanto ao rigor epistemológico da ciência histórica. No Brasil, Bittencourt (2009) indica que tal crítica aumentou à medida que mais historiadores foram formados nas primeiras Universidades brasileiras; Magalhães (2003) indica que internacionalmente associa às repercussões da École D'Annales, especialmente a partir da terceira geração, nos anos 1960. Tanto Braudel, representante da segunda geração, como Chartier e Le Goff, representantes da terceira geração, articulam-se no sentido de a disciplina histórica escolar começar a articular conceitos e apropriações da Ciência Histórica acadêmica.

Essa tendência se caracteriza pela prelazia aos saberes historiográficos envolvidos na definição dos conteúdos a serem ministrados, embasados na historiografia do século XX, que visam romper com o entendimento de ciência histórica até então vigente. Conforme aponta Burke (1997), com a École D’Annales e suas repercussões nos estudos da Micro-História, da História Social e da História Cultural, a História ensinada passa a contemplar uma gama maior de fontes e objetos de estudo. Mais que isso: o currículo da História escolar começa a 
ter contato com as produções fronteiriças da História e de outras ciências a ela interdisciplinares. Contudo, o que apontam seus críticos (sobremaneira os inseridos nas tendências que explicaremos posteriormente) é: que não rompem com práticas docentes de excessiva oralidade; que não partem nem de uma perspectiva de Ensino de História calcada na pesquisa nem da manipulação de fontes históricas por parte dos alunos; e é centrada excessivamente no ensino e no professor, e não na Didática da História (aprendizagem dos estudantes). Ashby (2003, p. 43) é enfática ao determinar: “[...] não se ensina um ensino de História crítico de fato se apenas os professores são críticos".

Esta terceira tendência atende aos dois primeiros critérios supracitados de saber da ação pedagógica, mas não ao terceiro, por justamente não ressignificar os saberes pedagógicos e não constituir uma nova Didática da História. Excessivamente dicotomizador dos saberes históricos aos saberes pedagógicos, é a tendência mais difundida no presente momento no Brasil e, como veremos nas falas dos sujeitos de pesquisa, presente até mesmo dentre os ditos especializados em formação docente em História. Por tal razão, não nos furtamos a questionar, uma vez que indica se calcar nos saberes históricos: por que persiste uma oralidade expositiva excessiva e uma negação sistemática ou velada do contato com estudantes ao métier do historiador e da pesquisa histórica em práticas docentes de professores de História, formados para entender História como conhecimento oriundo da pesquisa, das perguntas e do contato com fontes variadas?

É em tentativa de resposta a essa pergunta que, em meados dos anos 1980, se tem a criação e constante esforço de consolidação de outras práticas de ensino (e pesquisas acerca destas) que, sobretudo, partam da promoção do contato de estudantes com fontes históricas e com as metodologias do historiador, tanto na França como na América do Sul. Nomearemos este conjunto de outras práticas de ensino e pesquisa sobre Ensino de História de: "Ensino de História mediado por fontes". Nesse sentido, uma importante preocupação formativa dos professores de História em curso é observada nas produções dessa tendência, buscando romper com o ciclo reprodutivo de um Ensino de História restrito aos saberes historiográficos, articulando as ciências da Educação com as perspectivas da História Temática, da História Social e da Nova História Cultural.

Partindo do uso (e análise) de fontes variadas para suscitar diversas temáticas, mas adequando as práticas de ensino de História às linguagens metodológicas problematizadoras da Educação, ocorre uma junção de epistemologias que torna o Ensino de História um saber 
da ação pedagógica de fato, ressignificando a formação docente em História no Brasil nos últimos 25 anos, sobretudo a partir de narrativas de experiências formativas apontadas nas coletâneas organizadas por Bittencourt (2001) e Zamboni; Fonseca (2008).

Próximo a essa perspectiva supracitada, mas com diferenças significativas, se localiza a tendência da Educação Histórica, cuja preocupação em “aprendizagem histórica” é então semelhante ao do que chamamos de "Ensino de História mediado por fontes", mas vai para muito além (sem se desvincular) do pensado por Gauthier et al (1998) como "saberes da ação pedagógica". Por isso, Magalhães (2003, p. 113) argumenta que é fundamental compreender a relação entre Educação Histórica e Didática da História, uma vez que:

[...] não caberá à didáctica da História assumir um papel de mero laboratório de métodos e técnicas universalmente aplicáveis, mas antes centrar-se na especificidade do conhecimento histórico para as necessárias transposições didácticas. Deste ponto de vista, assume grande relevância a investigação que tem sido feita, nas últimas décadas, sobre o pensamento de alunos e professores, no âmbito específico da História. Por esta razão se inventariam, tão detalhadamente quanto possível, os estudos realizados, no Reino Unido, em alguns outros países da Europa, nomeadamente em Portugal, e nos Estados Unidos sobre esta temática. Do quadro traçado, importa sublinhar a pertinência dos estudos que permitem compreender como é que alunos aprendem História, que estratégias de aprendizagem desenvolvem, como é que o recurso à utilização de metodologias adequadas permite desenvolver e melhorar essas aprendizagens. Igualmente importante é o conhecimento das concepções dos professores sobre a natureza da sua disciplina e sobre o seu ensino, já que a investigação tem contribuído para tornar patentes as relações entre essas concepções e as práticas docentes.

Magalhães (2003) argumenta que os estudos acerca das práticas docentes em História que partem das premissas da Didática da História (ou seja, na ênfase da aprendizagem histórica) são os da Educação Histórica, diferenciando esses estudos das tendências dos estudos cognitivistas (que dão peso excessivo a aspectos cognitivos na aprendizagem), indicando que apesar de partir de uma investigação cognitivista (pensamentos e concepções prévias de alunos e de professores sobre História, sendo chamados esses estudos de “Cognição Histórica"), transpõem esse aspecto meramente cognitivo para centrar-se em propostas de saberes da ação pedagógica que vislumbrem melhorias da aprendizagem em História. Ainda: diferenciam-se de outros estudos em Ensino de História por considerarem tanto a aprendizagem dos sujeitos adquirida via processo de ensino, como a aprendizagem para além do ensino, por meio das práticas culturais (sobretudo da cultura histórica e da relação com o conhecimento histórico) e das relações sociohistoricamente situadas. 
Barca (2001, p. 15) aprofunda a relação entre esses estudos cognitivistas em História e Educação Histórica, mostrando como esses estudos contribuem tanto para a epistemologia do conhecimento cognitivista como para os estudos em História:

[...] A pesquisa (as pesquisas em geral da Educação Histórica) de inspiração construtivista - que busca responder à questão central: 'como é que os sujeitos constroem as suas idéias?' - tem revelado que crianças e adolescentes operam com aparatos conceptuais bem mais complexos do que a aplicação redutora de 'velhas' teorias de desenvolvimento à educação advogam que [...] o discurso escolar sobre cognição continua a centrar-se sobre idéias estereotipadas e abstractas sobre o desenvolvimento cognitivo, catalogando o raciocínio das crianças em pensamento concreto e o dos adolescentes em pensamento abstracto, como se não houvesse variâncias.

Barca (2011) demonstra então que os estudos em Educação Histórica, partindo dos conhecimentos históricos mobilizados (competências históricas) de jovens em vários países, apontam que os saberes históricos se aperfeiçoam com o contato com sujeitos historicamente maduros e situações-problema que envolvam pesquisas e reflexões a partir de análise de fontes históricas; estas reflexões incidem diretamente na ressignificação de práticas de ensino de História e na formação docente dos historiadores. Já se sinalizam experiências em formação de professores de História no Brasil partindo desta tendência na década passada, como os dos livros organizados por Zamboni; Fonseca (2008) e Schmidt; Cainelli (2009), o que implica afirmar que a Educação Histórica também já se configura como saber da ação pedagógica, atendendo aos três princípios defendidos por Gauthier et al (1998). Constatamos, com o levantamento bibliográfico aqui tomado como referencial para práticas docentes em História que as duas últimas tendências, efetivos saberes da ação pedagógica, coexistem com as três primeiras, sem ainda demarcar uma nova profissionalidade docente em História.

\section{Coletando dados acerca dos saberes da ação pedagógica}

Como coletar informações acerca dos saberes docentes, em especial os saberes da ação pedagógica, mobilizados por professores? Gauthier et al (1998) indica que são mediados pelas falas diretas acerca das práticas docentes específicas, ou de "ensino de", desde que permeiem gestão da matéria e do conteúdo; Monteiro (2007, p.117) é mais diretiva, acerca do ensino de História: "referem-se à articulação teórico-prática das perspectivas adotadas para o ensino de História". Portanto, quando questionamos os sujeitos de pesquisa acerca das escolhas das práticas docentes durante o semestre de 2015.1 (realizado na UECE entre junho a setembro desse ano), via perguntas acerca dos conteúdos, da estruturação das aulas e das metodologias empregadas, das formas de verificação da aprendizagem etc, já se esperam pistas acerca dos 
Linguagens, Educação e Sociedade, Teresina, Ano 23, n. 40, set./dez. 2018.

Revista do Programa de Pós- Graduação em Educação da UFPI| ISSN 2526-8449 (Eletrônico) 1518-0743 (Impresso)

https://doi.org/10.26694/les.v1i40.7753

saberes da ação pedagógica: com efeito, perguntamos direcionadamente acerca das perspectivas de ensino de História estes professores defendem e praticam/visam praticar.

Além disto, consideramos como Tardif; Lessard (2011) que há uma diversidade de formas de considerar os saberes docentes via falas dos professores, sobretudo quando os questionamos acerca do percurso formativo e profissional que percorreram, que em geral são evocados direta ou indiretamente durante as aulas. Considerando que são formadores de professores, as experiências docentes são poderosos referenciais formativos para futuras práticas, e também foram utilizados nesta pesquisa para cruzamento de dados. E como parte da análise, realizamos a observação das aulas de duas professoras que ministram as duas disciplinas iniciais da área de História e Ensino da UECE em Fortaleza, "Didática do Ensino de História" e "Metodologia do Ensino de História", em geral cursadas respectivamente entre o $3^{\mathrm{o}}$ e o $4^{\mathrm{o}}$ semestre, escolhidas justamente por serem de maior formação teóricometodológica acerca do Ensino de História na matriz curricular do curso, e que se aproximam dos critérios de verificação dos saberes da ação pedagógica de Monteiro (2007).

Nomeamos para esta pesquisa os professores a partir da sequência da disciplina na matriz curricular do curso, de acordo com o seguinte quadro:

Quadro 1 - Pseudônimos e disciplinas ministradas na área de História e Ensino

\begin{tabular}{|l|l|}
\hline Pseudônimo & Disciplina ministrada \\
\hline Professora A & Didática do Ensino de História- $3^{\mathbf{o}}$ semestre \\
\hline Professora B & $\begin{array}{l}\text { Metodologia do Ensino de História- } 4^{\mathbf{0}} \\
\text { semestre }\end{array}$ \\
\hline Professora C (coordenadora do curso) & Ação Educativa Patrimonial - $6^{\mathbf{0}}$ semestre \\
\hline Professor D & Prática Docente I - $7^{\mathbf{o}}$ semestre \\
\hline Professor E & Prática Docente II- $8^{\mathbf{o}}$ semestre \\
\hline Professor F & Laboratório de História e Ensino- eletiva \\
\hline
\end{tabular}

Fonte: Elaboração própria (2018).

Para fins de melhor articulação das temáticas específicas analisadas por nós neste artigo, abordaremos os dados recolhidos acerca das professoras A e B, pois traremos tanto os dados coletados na entrevista como os coletados na observação das aulas da disciplina. Os apresentaremos separadamente, por professora, preservando a lógica de que cada saber se relaciona com a autorreflexidade de cada docente e é formado ao longo da vida de cada um; 
Linguagens, Educação e Sociedade, Teresina, Ano 23, n. 40, set./dez. 2018.

Revista do Programa de Pós- Graduação em Educação da UFPI| ISSN 2526-8449 (Eletrônico) 1518-0743 (Impresso)

https://doi.org/10.26694/les.v1i40.7753

ao mesmo tempo, situaremos como cada mobilização de saber se coaduna com o caso analisado e com o contexto dos professores-formadores e dos historiadores de formação.

\section{Saberes da ação pedagógica entre outros referenciais para a prática docente na fala de professores da área de História e Ensino da UECE}

Quais os percursos formativos dos professores da área de História e Ensino do curso de Historia da UECE em Fortaleza? Quais os referenciais para prática docente e, consequentemente, referenciais de formação docente dos sujeitos de pesquisa? $\mathrm{Na}$ formulação de nossa pesquisa que visa apreender os saberes da ação pedagógica de professoresformadores que estas duas perguntas fazem mais sentido se relacionadas. Vejamos como o tripé formação-saberes-práticas se articula na trajetória e nas falas das duas professoras:

\section{Professora A}

A Professora A é formada em História pela UECE, especialista em História das Ideias Pedagógicas pela mesma universidade, mestra e doutora em Educação por outra universidade pública cearense; ministra a disciplina de Didática do Ensino de História no curso de História da UECE em Fortaleza desde o ano de 2007; e é docente com larga experiência no Ensino Superior e com experiência na Educação Básica. De diversas falas acerca de sua trajetória formativa, destacaremos algumas significativas acerca de como a professora buscou construir seu repertório de referenciais docentes:

[...] eu tive uma professora de História que ela era bem na linha positivista, naquela História mesmo que dava ênfase às datas comemorativas: os grandes marcos da História nacional ou da História mundial, e a professora pedia literalmente para decorar essas datas, os fatos, os nomes dos presidentes da República, dos reis, enfim. Isso mais ou menos na quinta... sexto ano hoje, sétimo ano, no início do chamado Primeiro Grau, que antes era o Ginasial. [...] eu tinha uma experiência de vida, de aproximação com a História, porque meu pai era professor de História, só que ele lecionava da sétima série em diante. [...] mesmo tendo essas experiências traumáticas, de ter aquela obrigação de decorar nomes, fatos e grandes eventos, eu gostava da História, porque em casa eu lia os livros que meu pai tinha, com os quais ele lecionava; e eu gostava de ler sobre a História do Egito, a História de Roma, gostava muito da Antiguidade, tanto a Oriental como a Clássica; e, na sétima série, com meu pai, essa aproximação, esse gosto pela História foi se tornando bem maior [...] Com meu pai como professor, apesar de ainda ser um período marcado pelo tradicionalismo, pelo positivismo, meu pai fugia à regra, porque ele era uma pessoa que era um amante mesmo da História e transmitia o conhecimento de uma forma leve, não era aquela coisa pesada de estar mandando decorar; fazia com que a gente viajasse mesmo: contava fatos, lendas, fábulas e encantava as 
pessoas, porque ele falava muito bem, se expressava muito bem e contava de um jeito interessante, às vezes até engraçado. Isso foi me aproximando e deixando mais esse gosto mesmo pela História. [...] me lembro mais da Educação Moral e Cívica, que era obrigatória naquele momento, no primeiro ano do Segundo Grau do que mesmo a História, porque inclusive era o mesmo professor que lecionava História, Educação Moral e Cívica e $O S P B$, eram as disciplinas; e ela foi tão insignificante, eu acho, que eu não consigo lembrar das aulas de História no Ensino Médio. [...] Agora, com a entrevista, foi que eu me toquei que se apagaram as aulas de História no Ensino Médio, o que me lembra é mais a da época em que eu estudava com meu pai e tinha que mostrar que estava estudando mesmo, então estudar para a prova de História era assim: tem que estudar para tirar um dez. [...] minha maneira de pensar, inclusive, assim, meu pai me inspirou na forma de eu trabalhar com alunos de Primeiro e Segundo Grau, ou de Ensino Fundamental e Médio, ele foi muito importante, foi minha fonte de inspiração mesmo, até a forma de dar aula, de trazer alguma coisa, eu sempre gostei de levar alguma curiosidade, suscitar outras formas de aprender a História: através de uma música, através de uma poesia, através de uma fábula, meu pai fazia muito isso. (PROFESSORA A, 2015).

A formação escolar mobiliza saberes da experiência e da tradição escolar que fazem parte, segundo Tardif (2008), dos referenciais para o ensino de História que permitem à professora ter experienciado as perspectivas do Ensino de História Tradicional/Humanista e do dito Científico (as primeiras duas tendências apontadas anteriormente); por conta das relações afetivas com seu pai, apreendeu destas vivências as boas práticas constituídas por ele e dos demais as relações negativas relacionadas com a gestão da disciplina História e da aula, inclusive obliterando memórias de outros períodos de formação escolar. Por sua força orientadora de futuros profissionais, igualmente é mobilizado sob a forma de conteúdo da disciplina de Didática do Ensino de História, uma vez que várias temáticas da disciplina favoreciam a discussão sobre os saberes escolares, bem como sobre saberes docentes em geral $^{2}$, e isso não ocorre apenas pelas temáticas e textos escolhidos: a professora se referia a esse período formativo como um saber utilizado ${ }^{3}$.

\footnotetext{
${ }^{2}$ Por exemplo, nas aulas 3 e 4: "Didática e saberes docentes: um debate atual", a partir dos textos de Fonseca (2009), Franco (2010), Tardif (2008) e Pimenta (2010), a "cultura escolar" e a "disciplina escolar"; aulas 4 a 6 : "História como disciplina escolar" e "Conteúdos e métodos do ensino de História: breve abordagem histórica", a partir dos textos de Bittencourt (2009). Igualmente, discussões sobre a História da Educação e a História do Ensino de História - aulas 6 e 7 -, além das aulas 10 e 11, via slides e/ou os textos de Schmidt e Cainelli (2009). Isso mostra o que Gauthier et al (1998) afirmam: existe um caráter formativo dos saberes para a construção de uma profissionalidade docente.

${ }^{3} \mathrm{Na}$ aula 3, a professora contou sobre sua formação escolar, suas atitudes como estudante e por que escolheu História; na aula 4, contou sobre a sua experiência de estudante escolar com a Educação Moral e Cívica e a Organização Social e Política Brasileira (OSPB), bem como sobre as aulas de Química; nas aulas 5 e 8, falou sobre a própria rotina escolar, como aluna de História e de outras disciplinas. Nessas e em outras aulas, os saberes da tradição pedagógica também aparecem, mesmo que não ligados à sua trajetória, falando sobre casos da tradição escolar via História da Educação.
} 
Linguagens, Educação e Sociedade, Teresina, Ano 23, n. 40, set./dez. 2018.

Revista do Programa de Pós- Graduação em Educação da UFPI| ISSN 2526-8449 (Eletrônico) 1518-0743 (Impresso)

https://doi.org/10.26694/les.v1i40.7753

Acerca da formação inicial, outros referenciais para a prática docente em História são formados, em damos destaque para uma formação teórico-metodológica entre a Metódica e a dita Científica, que segundo a professora eram tendências formativas nos cursos de História à época, de transição entre a Ditadura Civil-Militar e a reabertura política:

O curso de História era aquele currículo bem tradicional. Eu entrei em 1983 aqui; era já o fim do período da Ditadura Militar, um período já de abertura política, mas as marcas do regime ainda se encontravam aqui na UECE, por meio dos professores que lecionavam aqui. Eram vários os professores que eram militares do curso de História. Então, assim, era bem dentro daquela linha tradicional, inclusive as aulas eram bastante tradicionais, com esquema na lousa, com professor expondo. Alguns até faziam aquela imposição de que ele, como professor, tinha que expor e todo mundo ouvir, não havia debates, não havia participação dos alunos, era o professor lá expondo, expondo e expondo, depois fazia alguma pergunta ao aluno. Claro, eles cobravam leituras; [...], mas, apesar dos conteúdos ainda tradicionais, a forma como os professores trabalhavam [...] a gente sentia mudanças. A partir das leituras, a gente já estava despertando para outras coisas. E eu acho que depende muito da pessoa que busca outras leituras, que não fica só naquilo que o professor está recomendando, e tinham os professores que fugiam também desse modelo aí, tradicional.

[...] Apesar de os professores serem bastante tradicionais, [...] eu acho que aproveitei bastante. Posso citar aqui um professor que foi marcante: o que chamavam Coronel Oliveira, foi professor de História Moderna, História Contemporânea I; ele foi meu professor aí numas três disciplinas mais ou menos; ele tinha aquela postura tradicional de ainda usar aquela varinha, sabe? De bater na mesa ou bater na carteira para o aluno ficar olhando para ele; quando algum aluno estava cochilando, ele batia lá, mas, assim, eu aproveitava tanto aquelas leituras. Ele nos fez ler vários livros, textos e tinha aquela prova que era a prova escrita, mais dissertativa, não era um professor que... Ele deixava fluir, que a gente pudesse escrever, e não moldava a determinadas perguntas (como aconteceu com o outro professor), mas ainda era aquela percepção que, assim, você tem que responder, tem que desenvolver a questão de acordo com o que os autores estavam falando. Você tinha que estar ali de acordo com aqueles autores, mas ele, assim, foi importante. [...] Olhe, para você ter uma ideia, na minha formação, eu não ouvi falar nem em Nova História, Escola dos Annales, vagamente assim: o professor trabalhou com Introdução de Estudos Históricos, Teoria da História, também eram poucas disciplinas teóricas... Teoria da História era só uma, tinha Introdução aos Estudos Históricos e só. Metec ${ }^{4}$... Não obrigatoriedade de monografia, não tinha produção científica acadêmica no curso. Então era bem complicada mesmo a formação. (PROFESSORA A, 2015).

Já a formação didático-pedagógica, segundo a professora A, fora influenciada pelo praticismo tecnicista e a falta de relevância dos Estágios, cursados como "Prática Docente", para a professora, fato que se repete no caso de outros professores escutados durante a

\footnotetext{
${ }^{4}$ Seria concernente à atual disciplina de Métodos e Técnicas da Pesquisa Histórica.
} 
pesquisa. Destacamos a fala acerca dos Estágios pois se revela com clareza tanto a ausência do elemento "formação para o ensino de História" como pelos elementos destacados pela professora acerca de que tipo de gestão do conteúdo e da aula sua formação incidiu à época e como foi ressignificada sob a forma de saberes da ação pedagógica:

[...]Nada de Ensino de História, nada! Nada, nada, nenhum autor. Mas, em relação às práticas, também acho que foram super falhas [...]. Não aproveitei nada dessas práticas: [...] Ela dava as instruções e tal, claro, trazia alguns textos sobre prática de ensino, sobre... Nada voltado para a História! Mas, de uma maneira geral, de Ensino [...]. Aí, quando a gente chega lá, se apresenta [...] éramos orientados para fazer um período de observação. Éramos orientados para isso. Fomos ficar observando, observando a aula do professor e depois marcava um dia para cada aluno ministrar meia hora de aula, não me lembro se chegava a 40 minutos; porque eu me lembro que, no dia em que eu me apresentei, que eu fui dar aula, fazer essa prática para a professora observar, era eu e mais duas alunas, duas colegas, então a professora aproveitava uma aula, e os alunos, os estagiários, os graduandos, tinham lá tantos minutos para fazer uma exposição lá para aqueles alunos da escola. Para mim, foi também traumático, porque eu fiquei muito nervosa, porque sabia que ia ser observada. E você é jogada assim: você vai observar e depois você prepara a aula daquele conteúdo e vai lá! E me lembro também que ela fez algumas observações depois, mais relacionadas à questão mesmo da postura; não era nada de conteúdo, era mais assim: 'Fulano de tal falou rapidamente'; ou 'Falou com a voz muito alta', outro [...]. Ai eu me lembro que ela falou comigo, que eu falava de forma mais pausada e que eu tinha que ser mais... Entendeu? Falar de forma mais... [gestos indicando uma velocidade intensa]. '- Como assim?'. '- Você, para ser professora, tem que falar de forma mais austera, não sei, você tem que ter uma postura mais assim... Você é muito calma, tem que ser mais incisiva, não ser tão calma'. Então, assim, meu Deus do Céu! A minha personalidade... [...], quer dizer: isso vai refletir na minha maneira de ser professora, será que isso vai prejudicar? E hoje eu escuto muito os alunos dizerem que a minha calma é muito boa para eles. Aí é uma questão mesmo de perspectiva. (PROFESSORA A, 2015).

A lacuna da formação inicial para o ensino de História foi tema das aulas que observamos. Em quase todas as aulas alguma referência sobre lacunas formativas era evocada para constituir uma reflexão acerca da necessidade de uma formação sólida em ensino de História, objeto da disciplina ministrada, sobretudo na aula 06 da disciplina, em que a professora discutiu a categoria de "formação inicial" e de "saberes docentes". Assim, o saber da ação pedagógica se revela um "meta-saber", isto é, um saber formador de outros saberes, em que o formador de professores insere as próprias experiências dentro dos referenciais para o "ensino de", neste caso a História, em que a professora foi formada em uma situação e atua profissionalmente em favor de outra, mais aprofundada e especializada para o Ensino de História. Já a formação continuada também é significativa na formação da professora A tanto 
Linguagens, Educação e Sociedade, Teresina, Ano 23, n. 40, set./dez. 2018.

Revista do Programa de Pós- Graduação em Educação da UFPI| ISSN 2526-8449 (Eletrônico) 1518-0743 (Impresso)

https://doi.org/10.26694/les.v1i40.7753

para a pesquisa como para o ensino; se menos mencionada do que a formação inicial durante as aulas, ainda sim em vários momentos da disciplina o identificamos como saber da ação pedagógica. Na entrevista, a professora o mobiliza em vários momentos, como constituinte da formação de diversos tipos de saberes (da experiência, das ciências da educação, de repertório de práticas docentes), mas em destaque o da ação pedagógica pois a professora se afirma como pesquisadora do Ensino de História:

[...] Depois da impossibilidade de fazer esse doutorado na área de História (aqui não tinha mestrado em História), eu resolvi fazer na área de Educação, eu disse: 'Olhe, sou professora, amo minha profissão, aprendi realmente a amar a profissão de professora, de professora de História, então vou tentar um mestrado em Educação'; tentei na UFC e passei da primeira vez e com um tema, uma temática sobre Ensino de História. Aí pronto, aí começou a outra caminhada que me trouxe até aqui, que me trouxe à UECE, que me trouxe às pesquisas na área de Educação. Não me arrependi de fazer na área de Educação. Acho que isso representou muito. [...] sempre eu associei a minha vida como aluna ao que eu estava aprendendo, adquirindo de novo na Universidade, eu estava sempre tentando colocar isso em prática, a gente via assim... Inclusive as técnicas da professora... Ah, eu fazia com meus alunos aquelas técnicas! Aluno de Ensino Fundamental, Primeiro Grau, Segundo Grau, naquela época eram muito boas para eles essas dinâmicas. Eu tinha um livrinho da professora que consultava. Eu disse: 'Ah, vou utilizar essa técnica aqui!'; e, com os conteúdos, a gente cresce muito, porque [...] na especialização, embora numa área bem específica, mas aquilo já me dava conhecimento que dava para discutir; quando a gente trabalhava com a Revolução Francesa, trazia aqueles filósofos, conhecia um pouco mais. Então sempre o que eu estava aprendendo como aluna nos cursos de pós-graduação, ou num curso de aperfeiçoamento que, às vezes, fazia como professor, estava sempre acrescentando na minha prática como professora.

Destacamos que, dentre as escolhas discursivas da professora A, ela articula a formação como pesquisadora em Ensino de História e a de professora universitária, formadora de professores, o que reafirma a condição do saber da ação pedagógica funcionando como um meta-saber. Esta fala coaduna com sua resposta acerca de seus saberes da ação pedagógica:

Professora A: Olha a perspectiva de Ensino de História que eu tenho é... Eu sempre [...] levo em conta aquilo que me fundamenta nas minhas escritas, da História, da minha experiência também como pesquisadora. Eu sempre busco trabalhar nessa perspectiva da História Social, principalmente a História Social Inglesa, eu não... Mas assim: eu acho que nunca tem uma corrente historiográfica ali que está orientando só aquilo, mas nós temos também influência daquilo que a gente acha que é positivo, outras correntes como a Nova História, A História Nova Francesa... [...] eu acho que trabalhar a História é ter essa perspectiva social mesmo e de perceber um tempo que é um tempo que não é um tempo linear, é um tempo misturado, que é um tempo de agora, de antes, de vários agoras, de vários passados, com tempos convivendo simultaneamente, e de ver a História como um... De 
sempre levar em conta que a História tem por objeto o tempo, o tempo histórico, a gente tem que entender os dados, os acontecimentos a partir da compreensão daquele tempo, de entender as pessoas, as ações dos homens no contexto em que eles viveram. [...]

Pesquisador: Então é o Ensino de História influenciado pela História Social?

Professora A: E sem aquela coisa assim, a dicotomia entre quem é o bandido, quem é o herói, quem é o oprimido, sabendo que existem essas relações... Mas sabendo que não é só essa relação mecanicista, eu estou nessa posição, eu sou o oprimido e o outro é o opressor, mas que: eu sou o oprimido neste momento, mas que também tenho que perceber o que existiu em termos de movimentos, de tentativas daquele momento vivido por aquelas pessoas, naquele momento oprimidas, de resistência, enfim: eu acho que entender essa História vinda de baixo, mas sem também estar traçando essas dicotomias ou extremismos que são perigosos. [...] g gente pode se apropriar muito da questão da interdisciplinaridade, inclusive da visão de documento histórico, de fonte histórica, das novas linguagens, que isso é importantíssimo para o Ensino, é fundamental para o Ensino, entendeu? Mas há algumas coisas da Nova História que eu não aceito, porque, às vezes, ela passa a pesquisa histórica ou a compreensão que se quer ter da História... fica, muitas vezes, fragmentada, não é?

Sem mencionar diretamente algum autor do Ensino de História em especial na entrevista [embora ela trabalhe com diversas obras formativas do ensino de História, como Fonseca (2009) e Bittencourt (2009) na disciplina observada], a professora se insere na perspectiva do Ensino de História mediada por fontes, em que seu métier docente é articulado por sua compreensão histórica formada pela atuação como pesquisadora e professora. Contudo, é notório que quando perguntada sobre posicionamentos teórico-metodológicos do campo de estudos em Ensino de História, a professora se remeteu a compreensões mais da disciplina de referência (como veremos mais à frente, não foi a única). Acerca disso, Bittencourt (2009) e Oliveira (2001) apontam os perigos de uma superposição dos saberes disciplinares aos saberes da prática docente, inclusive entre os pesquisadores do Ensino de História; já Azevedo (2014, p. 125) demarca as dimensões do tempo e da historiografia como inescapáveis à percepção do professor de História como alguém sujeitado (pela Academia, pelas referências teóricas e conceituais da disciplina de referência), mas igualmente sujeito histórico, produtor de saberes pedagógicos sobre História.

Já ao relatar a trajetória da disciplina até o momento da entrevista e das escolhas metodológicas, a professora explicita seus referenciais para sua ação pedagógica:

[...] tenho como base para trabalhar com a Didática os teóricos pesquisadores da área do Ensino de História, como a Selva Guimarães Fonseca, a Circe Bittencourt, o Marcos Silva, principalmente Circe e Selva sempre foram duas autoras de que eu mais me aproximei, elas nos 
fundamentam bastante, além de outros pesquisadores, claro: (Thais) Nívia Fonseca, a própria Zamboni, mas é porque a Selva e a Bittencourt trabalham mais essas questões de Metodologia, fazendo essa discussão sobre a historiografia, o Ensino de História, as metodologias, as novas linguagens, a formação de professores, que a Selva trabalha bastante. E, claro, sem dispensar os teóricos da área da Educação que trabalham com a Didática: o Libâneo, a Selma Garrido Pimenta e outras pessoas da área de Didática. O próprio Libâneo é que tem embasado, assim, a minha proposta na área de Ensino de História.

[...] Trabalho muito com a exposição dialogada[...], uma aula em que a gente expõe, mas sempre levando em conta aquilo que o aluno já traz de leitura ou de entendimento sobre aquele assunto, e sempre tentando levar o aluno a participar da sala, porque eu fico impaciente quando eu vejo que o aluno está só ouvindo lá, às vezes, você percebe aluno que está longe, nem ouvindo ele está! Procuro trabalhar com essa questão do debate, essa participação efetiva dos alunos a partir da leitura, seminário, que neste ano eu enfatizei muito mais: vai ter um momento em que eles vão apresentar, fazer um painel. $\mathrm{Na}$ realidade, um painel não é seminário, não, mas eu trabalhei já muito com seminário, dividi semestres. Já antes eu pegava eram cinco livros e dividia por equipes - não sei se eram cinco livros, não. Eram livros, não era texto, mas livros, que os alunos iam ler e formavam um grupo em que eles fariam seminário sobre aquele livro; fiz isso muito também com outras turmas passadas. [...] Sempre eu busco dosar um pouco no momento em que eles vão apresentar, no momento em que eles vão fazer um debate, no momento em que eles podem fazer uma atividade até escrita mesmo, mas sempre focando a produção deles, que aí é o caso do portfólio, que tem esse objetivo de eles estarem registrando tudo o que está acontecendo na aula, o que eles estão lendo, o que eles estão fazendo: a experiência já do contato na escola, da entrevista com o professor. Eu acho que é um processo que a gente também está ajudando os alunos a realizar, a registrar as experiências deles nesse documento que é o portfólio. Então, assim, eu procuro trabalhar usando esses vários métodos de exposição oral, seminários com os alunos, debates [...], utilizando os slides, algum documentário. (PROFESSORA A, 2015).

O objetivo da disciplina é estabelecer um caminho interdisciplinar entre a Didática (especialmente via Epistemologia da Prática Docente) e a História, na constituição de um campo de estudos em Ensino de História orientador da aprendizagem de futuros docentes. Nesse sentido, ao partir de autores-referência e temáticas que compõem um repertório de conhecimentos próprios à inteligibilidade da docência na História, a disciplina forma saberes pedagógicos e da ação pedagógica primordialmente, requerendo de sua docente paralelamente esses mesmos saberes e uma formação adequada para isso. Se valendo do portfólio e dos debates, segundo a professora, se estabelece uma "exposição dialogada" que descentraliza o aprendizado como responsabilidade da criticidade do docente, e de forma mediada, parte das experiências dos estudantes com a Educação e com a História para compor sua metodologia. 
Usando o fator da observação das aulas como fonte de pesquisa, podemos considerar que a professora A conduziu uma série de mobilizações em sua prática vinculadas a aspectos de seus saberes (especialmente os da ação pedagógica e outros saberes experienciais) e de sua formação (de forma balanceada, falando de vários desses momentos experimentados em diferentes tempos), os quais a permitem indicar seu saber-poder, que a "autorizam" a ministrar tal disciplina. Mesmo com vasta experiência no Ensino Superior, 22 anos parcialmente interrompidos pelas formações continuadas de mestrado e de doutorado, isso não a impediu nem de enfrentar situações inusitadas nem de ousar e experimentar outras abordagens de ensino, outras leituras. Sem dúvida, todos os aspectos observados e coletados nas entrevistas a credenciam a estar docente na disciplina inicial da área de Ensino de História da UECE em Fortaleza e a colocam como elemento revelador de exceções dos dados da pesquisa bibliográfica: como uma professora especializada na área de Ensino de História.

\section{Professora B}

A Professora B é mestra e doutora em História pela mesma universidade paulista; ministra a disciplina de Metodologia do Ensino de História no curso de História da UECE em Fortaleza desde o ano de 2014. Tendo vasta experiência no Ensino Superior, embora pouca na Educação Básica (20 anos no Ensino Superior, sendo 18 na mesma Universidade em que se graduou, em São Paulo), adquiriu, ao longo de sua trajetória de vida, saberes experienciais, da disciplina de referência e da ação pedagógica bastante atrelados ao Ensino Superior, que são mobilizados em suas práticas de ensino. Ao falar de sua formação escolar, a professora se reporta aos saberes da tradição escolar:

[...] Eu tive uma experiência muito boa; eu só estudei durante a Educação Básica em duas instituições, eu acho que isso ajudou. Eu tive uma professora durante o Ensino Fundamental que hoje chama (Fundamental) II, que antigamente era de quinta a oitava série, que me acompanhou o tempo todo e, no Ensino Médio, uma outra. Então isso eu acho que faz diferença. E elas eram excelentes, tanto é que eu sempre digo isso: tenho certeza que eu fui fazer História por influência delas. Eu adorava! Não só a matéria, mas a maneira como elas lecionavam: elas faziam a gente ter interesse de fato pela matéria, então eu tive sorte. Eu acho que isso não é muito comum, mas eu acho que isso ajudou: ser a mesma professora que acompanhou a turma o tempo inteiro, tanto no Fundamental e depois no Médio, e elas eram/são minhas referências ainda hoje. (PROFESSORA B, 2015).

A professora B foi a única que não se reportou à formação inicial com ressalvas: o mais próximo disso foi o professor $\mathrm{F}$, de todos os sujeitos entrevistados na pesquisa (como já 
dissemos, suas falas não foram exploradas neste artigo). Em contrapartida, as outras referências à formação inicial são menos positivas, quando trabalhadas na disciplina de Metodologia do Ensino de História: na aula 4 da disciplina, em quatro momentos precisos da aula, mencionou e representou suas vivências como aluna de escola particular no período militar, usando-as como exemplo para a aula, inclusive no gestual de professores e alunos; já a aula 12 foi a aula em que ela mais falou sobre isso, lembrando-se do "decoreba das aulas de História e Português" via questionários, criticando a forma única de chegar a uma resposta matemática nas aulas de Matemática da segunda série. $\mathrm{O}$ fato de a professora $\mathrm{B}$, na entrevista, selecionar as boas experiências (e com História) e, nas aulas, destacar mais as experiências ruins (com História e com outras matérias) mostrou a relevância da observação de suas aulas.

Ela trouxe outras referências, sobretudo da História da Educação, para mobilizar os saberes da tradição escolar durante a aula várias vezes, como por exemplos: na aula 4, relatando suas experiências escolares no período militar, quando trouxe à tona a importância dos professores em saberem sobre o cotidiano escolar em outros tempos ${ }^{5}$; e na aula 5 , foi a tradição universitária evocada no período militar e em outros tempos, em desprivilegiar as licenciaturas. Como se pode perceber, tal qual a professora A, a professora B realizou a mobilização de seus saberes motivada pelos conteúdos da disciplina.

Sobre a formação inicial em uma Universidade particular de São Paulo, claramente a professora discute seus saberes históricos e saberes pedagógicos:

Professora B: A minha graduação foi numa licenciatura plena, de quatro anos, e a preocupação central era a formação docente, e eu acho que isso também era interessante: a coordenadora do curso na época tinha essa preocupação. Ela sempre falava [...] que o objetivo era esse. Eles queriam formar professores para a Educação Básica, com um perfil inclusive muito interessante. Ela dizia: '[...] em especial na rede pública, porque lá que há tanta carência! [...]'. Então esse era o foco, ela incentivava até a buscar esse caminho de lecionar, em especial na rede pública.

Pesquisador: Como é que foram as disciplinas de formação didáticopedagógica?

Professora B: A formação nessas disciplinas em especial eram dadas por professores da Educação; então era aquela coisa mais mesmo isolada do curso, por exemplo: disciplinas como Psicologia da Aprendizagem e Didática eram dadas por professores fora do curso de História. Era então uma psicóloga da área da Pedagogia, uma professora da Pedagogia; em Estrutura, que na época tinha Estrutura do Primeiro e do Segundo Grau, que basicamente era uma disciplina de legislação, era uma professora que vinha da Pedagogia. Enfim, não havia muito diálogo com o curso

\footnotetext{
${ }^{5} \mathrm{O}$ tema da aula, sobre História da Educação no período militar, facilitou a mobilização desse saber, pois diversas temáticas - sobre Educação Moral e Cívica (EMC) e Organização Social e Política Brasileira (OSPB) favoreciam essa discussão.
} 
especificamente de História, era uma coisa mais geral da Educação, que eu acho que é um problema.

Pesquisador: E as de Ensino de História?

Professora B: [...] tinha Estágio e eu não lembro se tinha outro nome, mas nós tínhamos disciplina de Estágio: era uma professora da História que nos acompanhava, do curso mesmo; e uma outra disciplina que eu não vou lembrar o nome que também era uma professora da História, que fazia uma espécie de Estudos de Caso, ela trazia [...] estudos de caso e era uma experiência mais ou menos assim... Mas, por exemplo: Didática, essa coisa... mas que, de acordo com aquela proposta, era a discussão que nos ajudaria a pensar como dar aula; coisas mais técnicas, 'como usar o quadro', 'como usar um filme', mas assim, de uma maneira geral, explicitamente, pensar no Ensino de História, 'como ensinar' independentemente do que você ensina [...], enfim, é possível uma discussão assim: há uma técnica, algo que sirva para todo mundo. [...] Durante a graduação, eu não assumi aulas, eu só fiz 'Estágio' mesmo, que era obrigatório do curso, e o nosso Estágio não previa regência.[...]. Eu tinha feito essa opção: eu queria lecionar só depois de formada, porque eu me sentia insegura.

Pesquisador: As disciplinas historiográficas, de alguma maneira, elas the ajudavam a perceber como o ensino de História se transcorreria?

Professora B: Sim, porque, assim, os professores do curso, em geral, eles também vieram, então a trajetória deles foi esta: eles eram professores da Educação Básica que foram fazendo seus cursos de mestrado e depois chegaram ao Ensino Superior. Então, embora nessas disciplinas mais, vamos chamar assim, teóricas, da área do conhecimento, a maioria (não todos é claro), mas a maioria dos professores tinha essa preocupação de pensar em como a gente faz nessa discussão em sala de aula, enfim como se pensa isso no ensino, porque eles foram professores também na Educação Básica, então eles tinham um pouco essa preocupação.

A professora B descreve uma experiência de formação inicial bastante diferente das demais falas dos professores da área de História e Ensino; tanto difere no tempo (anos 1990, enquanto os demais se formam entre os anos 1970 a 1980) como no espaço (a única formada fora do estado do Ceará). Percebe-se portanto a historicidade como elemento constitutivo importantes acerca dos fatores na formação dos saberes docentes; em se tratando da formação inicial, a historicidade toma outra dimensão, na medida em que certas posturas e escolhas de formação dialogam com as transformações nas concepções e condições de formação, nas possibilidade previstas pelo currículo prescrito e nas mudanças que só o currículo real revela, com a troca e as experiências formativas dos formadores de professores. Observa-se que a professora acusa o aparte das disciplinas pedagógicas à formação para a docência em História, o que nos levou a perguntar acerca da articulação com a escola básica nas disciplinas historiográficas. O mais destacável é que as disciplinas de Estágio foram significativas mais 
para aprender sobre a dinâmica escolar do que para formar os saberes da ação pedagógica, objetivo central dessas disciplinas.

$\mathrm{Na}$ formação continuada, a professora mostra mais proximidade com a disciplina ministrada, sobretudo como um saber da disciplina de referência, uma vez que tenha realizado mestrado e doutorado em História:

Pesquisador: Quanto a essas etapas de formação lato sensu, stricto sensu, como a senhora mobiliza esses saberes em suas aulas?

Professora B: Então, eu acho que [...] as leituras foram fundamentais, determinadas disciplinas, claro que nem todas, mas determinadas disciplinas foram assim fundamentais para que eu pensasse algumas coisas, as quais me ajudam até hoje [...]. Então, as leituras sobretudo [...] me deram assim condições de pensar e usar inclusive em determinadas discussões, e claro que a gente acaba se espelhando em uma série de práticas que a gente vê com os professores; alguns acaba tomando mesmo também como referência; uma das professoras, já que eu fiz mestrado e doutorado na mesma instituição (eu tive contato com alguns professores; tanto no mestrado como no doutorado era o mesmo corpo docente) [...] (além da minha orientadora, é óbvio, mas, com minha orientadora, basicamente, eu aprendi a fazer a pesquisa, porque eu fiz poucas disciplinas com ela) [...] em especial, [...] até nos meus agradecimentos do doutorado eu a menciono, eu acho que ela é também um modelo positivo a ser seguido. Eu brinco até com meus alunos, eu digo: 'Quando eu crescer, queria ser como ela!', porque é de fato um modelo bem positivo, uma profissional séria, dedicada, enfim, que leva a sério o ofício dela e faz os alunos também levarem a sério as aulas.

Ao mencionar a formação continuada, a professora curiosamente não falou da voltada para o Ensino (ela fez duas, mas só mencionou a de História): em Docência no Cenário do Ensino para a Compreensão, realizada durante o período do doutorado, na mesma Universidade na qual ensinava. Essa "predileção" pelo caminho formativo na História como elemento referenciador em suas aulas, como ela disse, faz sentido pela formação para a pesquisa: como colocado explicitamente na aula 10, em que ela contou uma parte de sua pesquisa sobre Música no mestrado e doutorado, mas implicitamente nas aulas da disciplina a partir da aula 5, quando a professora passa a discutir as linguagens no Ensino de História e precisa desses saberes para ensinar.

Os saberes da ação pedagógica também se manifestam na formação contínua, via prática docente. Contudo, nem sempre se manifestam via experiência de ensino na Educação Básica, mas de olhar externo, o que deixam a professora B em uma condição de exceção aos demais professores sujeitos de nossa pesquisa, mas semelhante a de outros professoresformadores entrevistados para outras pesquisas [vide Zamboni; Fonseca (2008)]: 
Pesquisador: Como é que você busca articular as reflexões sobre a Escola Básica e o Ensino de História?

Professora B: Então, eu estou há muito tempo afastada da sala de aula da Educação Básica, eu só fiquei, na verdade, lá dois anos. Então, desses 21 anos que eu leciono, dois deles eu passei lá, então há 19 anos que eu não estou em uma sala de aula da Educação Básica, então o meu contato é acompanhando o que acontece, via até os próprios alunos, e, claro, lendo e entendendo, mas é um olhar externo da Educação Básica. Então, o que eu procuro apresentar para os meus alunos é aquilo que está também nos documentos, é o que se espera do Ensino de História na Educação Básica, então, a partir dos Referenciais, a partir dos próprios Parâmetros Curriculares Nacionais, então: 'Qual é o papel da História na Educação Básica?'; 'O que se espera dessa disciplina?'. Então eu tento articular com eles uma discussão nesse sentido! Mas, assim, de vivência, está bem distante da minha realidade.

Tal qual a professora A, a professora B durante as aulas e a entrevista buscou também se situar em uma defesa de um Ensino de História mediado por fontes no curso de História da UECE em Fortaleza, que legitime a área de Ensino de História como de relevância histórica, calcada na teoria e metodologia da História, para que lentamente rompa com o que a professora se remete às trajetórias de formação nos cursos de História no Brasil. Ela o fez em declarado diálogo com os saberes das Ciências da Educação em vários momentos da disciplina, para não se limitar a discussões sobre saberes históricos isto se torna relevante sobretudo na compreensão de como ela mobiliza os saberes da ação pedagógica:

Então, eu acho que o Ensino de História é fundamental! E, desde a Educação Básica, eu acho que ele tem que servir para isto: para aprender a ler o contexto em que a gente vive, questionar a realidade em que a gente está inserido e entender o porquê dela, de como isso foi construído e como a gente pode interferir e mudar essa realidade. É de fato esse olhar crítico, mas tem que ser de fato desenvolvido e de fato a construção de uma cidadania, ter essa criticidade, saber por que as circunstâncias são essas. Estamos na nossa cidade tal qual ela é com uma construção histórica, e é isso que a gente quer? Não quer? Como a gente interfere? Que limites [...], que possibilidades a gente tem na mudança? Eu acho que essa consciência [...] tem que ter de fato para exercer a nossa cidadania: sem essa consciência, [...] não é cidadão de fato! [...] Se a gente consegue fazer isso já na Educação Básica, pronto, todo o mérito, toda a importância da História lá foi alcançada. (PROFESSORA B, 2015)

O nexo orientador da disciplina consistiu em discutir com os licenciandos acerca do conhecimento pedagogizado da matéria, nomenclatura defendida por Monteiro (2007). Nesse sentido, os saberes da ação pedagógica, via conhecimento pedagogizado da matéria, suscitam caminhos de formação docente. A tônica da disciplina favorece maior interação na prática de um Ensino de História mediado por fontes, que seja problematizador e promotor de um ensino 
Linguagens, Educação e Sociedade, Teresina, Ano 23, n. 40, set./dez. 2018.

Revista do Programa de Pós- Graduação em Educação da UFPI| ISSN 2526-8449 (Eletrônico) 1518-0743 (Impresso)

https://doi.org/10.26694/les.v1i40.7753

articulador de saberes pedagógicos e transversalmente preocupado com a aprendizagem histórica, por isso mesmo mediado pelo contato com as fontes. Por isso, atentamo-nos, de modo mais direcionado, à articulação dos saberes da ação pedagógica como conhecimento pedagogizado da matéria ${ }^{6}$ na observação das aulas da professora $\mathrm{B}$ e percebemos que os que a professora possui e os que a professora promove, nesse sentido, entrecruzam-se, mas não sempre coadunados.

No começo da disciplina, ela dominou a aula em torno de si, ao promover, via textos de Thais Fonseca e Selva Fonseca, bem como de outros autores, uma discussão panorâmica do campo do Ensino de História como pesquisa e como prática em sua trajetória histórica; apenas, vez ou outra, permitindo e/ou provocando poucas falas dos estudantes. Somente após o instrumento de verificação da aprendizagem via "prova escrita" (ocorrido na aula 6), da aula 7 da disciplina até a aula 14, em que cada aula versava acerca de uma linguagem, a professora mudou sensivelmente a postura da aula, sendo mais propositiva e constantemente se autoavaliando e pedindo a participação dos alunos na análise de fontes históricas que ela criteriosamente selecionava. A frase: “[...]Eu sei que eu falo demais, mas vamos participar", como mantra, foi constantemente evocada. $\mathrm{O}$ oralismo e a estrutura pétrea de aula, observados entre as aulas 3 e 5, foram sendo aos poucos quebrados por mais incursões de linguagem e mais debates, lentamente aceitos pelos estudantes ${ }^{7}$. Essa mudança não passa despercebida nas falas subsequentes da professora que traremos neste artigo.

Quanto aos conteúdos da disciplina, a professora B busca destacar que tentou articular os distintos saberes que possui para ministrar a disciplina, uma afirmação de saber-poder dos conhecimentos pedagógicos:

Então eu acho que não só as discussões sobre o Ensino, porque eu acho que, para ensinar Metodologia do Ensino de História, você, além de ter obviamente referências sobre Metodologia, você tem que pensar a área como um todo; eu acho que é importante também discutir: formação docente; Como nos tornamos professores, mas é claro: a questão é pensar como se faz essa transposição, ajudar os alunos a entenderem essa questão de como eles conseguem fazer essa transposição ${ }^{8}$ desses saberes que eles

\footnotetext{
${ }^{6}$ Aula 7: imagens nos livros didáticos; aula 8: literatura; aula 9: cinema; aula 10: músicas; aula 11: imprensa; aula 12: documentos escritos; aula 14: museus. Perceba que o foco é indicar sugestões de usos mediante possibilidades de análise das fontes históricas em questão nas aulas de História.

${ }^{7}$ Nas aulas 7, 10 e 12, a professora teve menos dificuldade de conseguir a participação dos alunos. Nas demais, era mais evidente que a docente perguntava mais para conseguir participação. A última observada, sobre museus, foi a aula em que a professora fez mais perguntas.

8 A professora B fala em "transposição" (didática), conceito rebatido por Bittencourt (2009) e Monteiro (2007), mas se orienta na primeira e em Fonseca (2009) - inclusive citando o título de um capítulo desse texto dela,
} 
foram acumulando e construindo aqui durante o curso todo para sala de aula, para as necessidades, para o público que eles terão. (PROFESSORA $B, 2015)$

E destaca a articulação de distintos saberes na composição da mobilização de seu saber da ação pedagógica:

[...] as minhas aulas são sobretudo expositivas, eu apresento o texto, embora eu indique com antecedência; no primeiro dia de aula, eu entrego para os alunos o nosso cronograma além do planejamento da disciplina como um todo, com ementa, enfim, eles recebem um cronograma com a temática e o texto de aula; cada aula tem um texto com o que a gente vai discutir, e a ideia é que eles leiam para trazer dúvidas, questões, para [...] discutir em sala de aula, mas assim: pouco acontece! Poucos alunos leem com antecedência por uma série de questões, então acaba que eu sempre (esse é meu modo de dar aula, sempre): desde o primeiro dia que eu comecei a lecionar, para eu explicar algum tema, apresentar alguma discussão, eu tenho que ir para o quadro, eu faço um esquema, que é mais ou menos uma síntese do que eu vou apresentar, e exponho. E, em alguns momentos, quando é possível, aí a gente amplia com textos complementares, que eu geralmente levo trechos para serem lidos em sala de aula para suscitar algumas discussões, quando há possibilidade, claro: documentário, filme, quando cabe naquela discussão, mas não é recorrente; eu não uso recursos de multimídia, não porque eu não goste, mas não necessariamente em toda aula eles são úteis e têm ali uma função. Geralmente, eu apresento a discussão no quadro e vou discutindo com eles.

Pesquisador: Percebo o uso das fontes, por exemplo: como é que é usar essas fontes?

Professora B: Eu acho que isso é importante, trazer para os alunos essa documentação. Fazer com que eles exercitem um pouco isso de fazer análise, a partir delas em sala de aula, eu acho que também é interessante.

Percebemos, ao longo da entrevista e das observações em sala de aula, que a professora B optou por um caminho distinto do escolhido pela professora A, enfatizando os saberes da ação pedagógica e reforçando os saberes históricos, para tentar sensibilizar os estudantes para a disciplina ministrada. As escolhas metodológicas, por discutirem as linguagens históricas, mesmo previstas pela professora e pela ementa da disciplina, foram a tônica dominante na metade final do semestre letivo.

Acompanhando essa trajetória da disciplina percorrida pela professora e seus discentes, é inquestionável que o ponto de encontro entre essas duas dimensões foram os aspectos metodológicos da análise das fontes, aspecto significativo por duas razões: 1) a força dos saberes disciplinares na construção dos saberes da ação pedagógica mostra a ainda relutante hierarquia de saberes nas representações de formação historiográfica, sobretudo por

usado na disciplina de Didática do Ensino de História, ministrada pela professora A -, como saberes da ação pedagógica a serem ministrados na condição de conhecimento pedagogizado da matéria. 
Linguagens, Educação e Sociedade, Teresina, Ano 23, n. 40, set./dez. 2018.

Revista do Programa de Pós- Graduação em Educação da UFPI| ISSN 2526-8449 (Eletrônico) 1518-0743 (Impresso)

https://doi.org/10.26694/les.v1i40.7753

parte dos estudantes, que, como observamos, mais dialogavam no aspecto interno metodológico das fontes do que na hora de discutirem caminhos de atuação docente via uso dessas fontes, apesar dos esforços da professora; 2) a docente, por diversas vezes, mais reforçava esse caminho historiográfico do Ensino de História do que discutia os aspectos pedagógicos desse campo de conhecimento. Como Rüsen (2011) aponta, isso não é necessariamente um erro metodológico dos professores de História, mas acaba por separar os elementos da Didática e da História, em vez de criar uma sinergia de saberes para fortalecer a Didática da História.

Apesar de reforçar os saberes históricos de referência ao longo da disciplina, a professora B também mostra se legitimar como docente nessa disciplina por outras razões; faz conexões com as demais disciplinas historiográficas que ministra no curso, como História do Brasil I, História do Brasil III e História do Brasil IV, bem como com outras disciplinas do curso, sejam disciplinas da área de Ensino de História, sejam disciplinas de formação direcionadas à formação teórica e metodológica. Em pouco tempo de experiência no curso, já ministrou outras três disciplinas na área de História e Ensino no curso de História da UECE em Fortaleza, como Oficina de Instrumentos Didáticos, Ação Educativa Patrimonial e Laboratório de História e Ensino. Na vasta experiência adquirida na outra Universidade em que atuou, ministrou diversas disciplinas atreladas à Educação, como por exemplo "Pesquisa em Educação" e "Docência: Aspectos Sociais, Políticos e Pedagógicos".

Nesse sentido, a professora B acaba por ser um exemplo de como o caso da área de Ensino de História da UECE em Fortaleza é, ao mesmo tempo, um confirmador da regra e uma exceção à maioria das licenciaturas em História no Brasil: é uma docente que, embora em sua formação continuada não tenha atuação de pesquisa em Ensino de História, construiu elementos de formação contínua e saberes da experiência para se legitimar como docente nessa disciplina, mobilizando em sua prática vários saberes pedagógicos e da ação pedagógica para formar futuros professores de História, mesmo que, por vezes, reforce mais os saberes da disciplina de referência.

\section{Considerações finais}

Investigar os saberes da ação pedagógica de professores é, ao mesmo tempo, considerar o percurso formativo, o conjunto dos demais saberes e as práticas docentes; é considerar a sinergia da práxis docente em suas variadas instâncias e potencialidades, 


\section{Linguagens, Educação e Sociedade, Teresina, Ano 23, n. 40, set./dez. 2018.}

Revista do Programa de Pós- Graduação em Educação da UFPI| ISSN 2526-8449 (Eletrônico) 1518-0743 (Impresso)

https://doi.org/10.26694/les.v1i40.7753

ponderando desde os referenciais docentes praticados e/ou mencionados. Ao longo de nossa investigação, ficaram mais aparentes os dados acerca dos saberes da ação pedagógica destas duas professoras do que dos demais sujeitos de pesquisa que entrevistamos, por escolhas metodológicas, mas que revelaram significativas acerca tanto do locus de atuação destes como do conjunto dos professores que atuam dentro deste espaço.

Assim, dialogando com as pesquisas já realizadas acerca dos cursos de formação de professores (e com efeito, de História), temos dois perfis docentes que agregam tanto elementos em comum (entre si e a vários formadores de professores de História) como peculiaridades inscritas da trajetória formativa de cada um. Entre uma especialista na área que atua e outra que se adapta à condição de formadora de professores, variadas ênfases formativas necessitam de distintos saberes docentes. Mesmo que as disciplinas ministradas prescrevam a prelazia dos saberes da ação pedagógica (neste caso, saberes do Ensino de História), em determinados momentos das disciplinas observadas isto não ocorreu (o que é perfeitamente compreensível, uma vez que para formar outros docentes um professor necessite mobilizar toda sorte de saberes), ou ocorreu a prelazia de saberes históricos. Quando mobilizados, nem sempre foram na perspectiva de um Ensino de História mediado por fontes, hoje consenso [vide ZAMBONI; FONSECA (2008)] nos trabalhos em Ensino de História como o novo modelo formativo em voga, ainda com resquícios de um aulismo expositivo, reconhecido pelas próprias professoras entrevistadas. Felizmente, esta perspectiva foi a mais empregada pelas professoras, como demonstramos anteriormente, revelando que estas docentes estão atualizadas acerca das perspectivas formativas dos professores de História.

A variedade de dados recolhidos acerca dos saberes docentes mobilizados pelas professoras aponta a necessidade de mais pesquisas neste campo de investigação, a fim de elucidar e propor melhorias na formação de professores no Brasil. Nossa pesquisa já colabora neste campo em quatro sentidos, por: 1) destacar a necessidade, sobretudo por coerência acerca da docência em uma licenciatura - portanto voltada essencialmente para a formação de professores - de ter professores especializados (pesquisadores e dotados de um repertório vasto saberes da ação pedagógica) em Ensino de História ministrando as disciplinas direcionadas para a formação didática ou que, pelo menos, dominem, pela teoria e pela prática, os saberes da ação pedagógica para formar outros professores; 2) tornar relevante a compreensão de que os saberes da ação pedagógica são constantemente produzidos e renovados, e do quão necessária é a atualização dos docentes para formar outros de maneira 
Linguagens, Educação e Sociedade, Teresina, Ano 23, n. 40, set./dez. 2018.

Revista do Programa de Pós- Graduação em Educação da UFPI| ISSN 2526-8449 (Eletrônico) 1518-0743 (Impresso)

https://doi.org/10.26694/les.v1i40.7753

competente e promotora de mudanças sociais; 3) ressaltar que, apesar de existirem disciplinas voltadas para formação em Ensino de História, todo o projeto pedagógico em uma licenciatura deve estar voltado para a formação de professores, para que o processo formativo como um todo possa, de alguma forma, construir o repertório de saberes da ação pedagógica e assim futuros professores de História tenham condições de formar outros professores; 4) indicar que a experiência docente na Educação Básica, não apenas em Docência Universitária ou em Formação de Professores, causa grande impacto na formação docente dos formadores de professores, pois estes mobilizam os saberes docentes sob a forma de um meta-saber, um conhecimento de causa, o que aproxima os futuros docentes ao exercício do ensino, como uma experiência possível de se realizar. Diante das considerações supraexpostas, se depreende a necessidade de se repensar as diretrizes acerca das formações dos professores no Brasil, que devem valorizar os saberes integradores voltados à prática docente (sobretudo valorizar os saberes da ação pedagógica); bem como repensar os critérios de seleção e concurso de professores formadores no cenário nacional.

\section{REFERÊNCIAS}

ALMEIDA, M. I. A formação do professor do ensino superior: desafios e políticas institucionais. São Paulo: Cortez, 2012.

ASHBY, R. O conceito de evidência histórica: exigências curriculares e concepções de alunos. In: BARCA, I. (Org.). Educação histórica e museus. Braga: Universidade do Minho: Lusografe, 2003. p. 37-55.

AZEVEDO, P. B. História ensinada e prática escolar de letramento: tempo-espaço de correlações de força e poder. In: GABRIEL, C. T.; MORAES, L. M. S. (Org.). Currículo e conhecimento: diferentes perspectivas teóricas e abordagens metodológicas. Petrópolis: De Petrus, 2014. p. 117-132.

BARCA, I. Educação histórica: uma nova área de investigação. Revista da Faculdade de Letras: História, Porto, III série, v. 2, p. 13-21, 2001.

BITTENCOURT, C. (Org.). O saber histórico em sala de aula. 4. ed. São Paulo: Contexto, 2001. p. 11-27. (Repensando o Ensino).

BITTENCOURT, C. Ensino de História: fundamentos e métodos. 3. ed. São Paulo: Cortez, 2009.

BURKE, P. A escola dos Annales 1929-1989: a revolução francesa da historiografia. São Paulo: Unesp, 1997. 
Linguagens, Educação e Sociedade, Teresina, Ano 23, n. 40, set./dez. 2018.

Revista do Programa de Pós- Graduação em Educação da UFPI| ISSN 2526-8449 (Eletrônico) 1518-0743 (Impresso)

https://doi.org/10.26694/les.v1i40.7753

FONSECA, S. G. Didática e prática de ensino de História: experiências, reflexões e aprendizados. 8. ed. Campinas: Papirus, 2009.

FOUCAULT, M. A ordem do discurso. 15. ed. São Paulo: Loyola, 2007.

FRANCO, M. A. S. Didática e Pedagogia: da teoria de ensino à teoria da formação. In: FRANCO, M. A. S.; PIMENTA, S. G. (Org.). Didática: embates contemporâneos. São Paulo: Loyola, 2010. p. 75-100.

GAUTHIER, C. et al. Por uma teoria da pedagogia: pesquisas contemporâneas sobre o saber docente. Ijuí: Unijuí, 1998. (Coleção Fronteiras da Educação).

MAGALHÃES, O. Concepções de História e ensino de História. In: BARCA, I. (Org.). Educação histórica e museus. Braga: Universidade do Minho: Lusografe, 2003. p. 9-18.

MONTEIRO, A. M. Professores de História: entre saberes e práticas. Rio de Janeiro: Mauad X, 2007.

OLIVEIRA, M. M. D. O ensino de História como objeto de pesquisa. Saeculum: Revista de História, Paraíba, n. 6-7, p. 97-104, 2001.

PIMENTA, S. G. Epistemologia da Didática ressignificando a prática. In: FRANCO, M. A. S.; PIMENTA, S. G. (Org.). Didática: embates contemporâneos. São Paulo: Loyola, 2010. p. $15-41$.

RÜSEN, J. Didática da História: passado, presente e perspectivas a partir do caso alemão. In: SCHMIDT, M. A.; BARCA, I.; MARTINS, E. R. (Org.). Jörn Rüsen e o ensino de História. Curitiba: UFPR, 2011. p. 23-49.

SCHMIDT, M. A. M. S.; CAINELLI, M. Ensinar História: pensamento e ação na sala de aula. 2. ed. São Paulo: Scipione, 2009.

SCHÖN, D. A. Formar professores como profissionais reflexivos. In: NÓVOA, A. (Org.). Os professores e sua formação. Lisboa: Dom Quixote, 1992. p. 79-92

STAKE, R. E. A arte da investigação com estudos de caso. Lisboa: Gulbenkian, 2007.

TARDIF, M. Saberes docentes e formação profissional. 9. ed. Petrópolis: Vozes, 2008.

TARDIF, M.; LESSARD, C. O trabalho docente: elementos para uma teoria da docência como profissão de interações humanas. 6. ed. Rio de Janeiro: Vozes, 2011.

VEYNE, P. Como se escreve a História: Foucault revoluciona a História. Brasília, DF: UnB, 2008.

YIN, R. K. Estudo de caso: planejamento e métodos. 3. ed. Porto Alegre: Bookman, 2005. 
Linguagens, Educação e Sociedade, Teresina, Ano 23, n. 40, set./dez. 2018.

Revista do Programa de Pós- Graduação em Educação da UFPI| ISSN 2526-8449 (Eletrônico) 1518-0743 (Impresso)

https://doi.org/10.26694/les.v1i40.7753

ZAMBONI, E.; FONSECA, S. G. (Org.). Espaços de formação do professor de História. Campinas: Papirus, 2008.

Recebido em: 18.08 .2017

Aceito em: 16.11.2018 